\title{
Secondary calcification and dissolution respond differently to future ocean conditions
}

\author{
N. J. Silbiger and M. J. Donahue \\ University of Hawaii, at Manoa, Hawaii Institute of Marine Biology, PO Box 1346, Kaneohe, Hawaii \\ Correspondence to: N. J. Silbiger (silbiger@ hawaii.edu)
}

Received: 8 August 2014 - Published in Biogeosciences Discuss.: 2 September 2014

Revised: 15 December 2014 - Accepted: 18 December 2014 - Published: 29 January 2015

\begin{abstract}
Climate change threatens both the accretion and erosion processes that sustain coral reefs. Secondary calcification, bioerosion, and reef dissolution are integral to the structural complexity and long-term persistence of coral reefs, yet these processes have received less research attention than reef accretion by corals. In this study, we use climate scenarios from RCP 8.5 to examine the combined effects of rising ocean acidity and sea surface temperature (SST) on both secondary calcification and dissolution rates of a natural coral rubble community using a flow-through aquarium system. We found that secondary reef calcification and dissolution responded differently to the combined effect of $p \mathrm{CO}_{2}$ and temperature. Calcification had a non-linear response to the combined effect of $p \mathrm{CO}_{2}$ and temperature: the highest calcification rate occurred slightly above ambient conditions and the lowest calcification rate was in the highest temperature $-p \mathrm{CO}_{2}$ condition. In contrast, dissolution increased linearly with temperature- $p \mathrm{CO}_{2}$. The rubble community switched from net calcification to net dissolution at $+271 \mu$ atm $p \mathrm{CO}_{2}$ and $0.75^{\circ} \mathrm{C}$ above ambient conditions, suggesting that rubble reefs may shift from net calcification to net dissolution before the end of the century. Our results indicate that (i) dissolution may be more sensitive to climate change than calcification and (ii) that calcification and dissolution have different functional responses to climate stressors; this highlights the need to study the effects of climate stressors on both calcification and dissolution to predict future changes in coral reefs.
\end{abstract}

\section{Introduction}

In 2013, atmospheric carbon dioxide $\left(\mathrm{CO}_{2(\mathrm{~atm})}\right)$ reached an unprecedented milestone of $400 \mathrm{ppm}$ (Tans and Keeling, 2013), and this rising $\mathrm{CO}_{2 \text { (atm) }}$ is increasing sea surface temperature (SST) and ocean acidity (Caldeira and Wickett, 2003; Cubasch et al., 2013; Feely et al., 2004). Global SST has increased by $0.78^{\circ} \mathrm{C}$ since pre-industrial times (Cubasch et al., 2013), and it is predicted to increase by another 0.8 $5.7^{\circ} \mathrm{C}$ by the end of this century (Meinshausen et al., 2011; Van Vuuren et al., 2008; Rogelj et al., 2012). The Hawaii Ocean Time-series detected a 0.075 decrease in mean annual $\mathrm{pH}$ at station ALOHA over the past 20 years (Doney et al., 2009) and there have been similar trends at stations around the world, including the Bermuda Atlantic Time-series and the European Station for Time-series Observations in the ocean (Bindoff et al., 2007). pH is expected to drop by an additional $0.14-0.35 \mathrm{pH}$ units by the end of the twenty-first century (Bopp et al., 2013). All marine ecosystems are at risk from rising SST and decreasing $\mathrm{pH}$ (Doney et al., 2009; Hoegh-Guldberg et al., 2007; Hoegh-Guldberg and Bruno, 2010), but coral reefs are particularly vulnerable to these stressors (reviewed in Hoegh-Guldberg et al., 2007).

Corals create the structurally complex calcium carbonate $\left(\mathrm{CaCO}_{3}\right)$ foundation of coral reef ecosystems. This structural complexity is at risk from climate-driven shifts from highcomplexity, branched coral species to mounding and encrusting growth forms (Fabricius et al., 2011) and from increases in the natural processes of reef destruction, including bioerosion and dissolution (Wisshak et al., 2012, 2013; Tribollet et al., 2006). While substantial research attention has focused on the response of reef-building corals to climate change (reviewed in Hoegh-Guldberg et al., 2007; Fabricius, 2005; Pandolfi et al., 2011), secondary calcification (calcification 
by non-coral invertebrates and calcareous algae), bioerosion, and reef dissolution that are integral to maintaining the structural complexity and net growth of coral reefs has received less attention (Andersson and Gledhill, 2013; Andersson et al., 2011; Andersson and Mackenzie, 2012). Bioerosion and dissolution break down the reef framework, while secondary calcification helps maintain reef stability by cementing the reef together (Adey, 1998; Camoin and Montaggioni, 1994; Littler, 1973) and producing chemical cues that induce settlement of many invertebrate larvae including several species of corals (Harrington et al., 2004; Price, 2010). Coral reefs will only persist if constructive reef processes (growth by corals and secondary calcifiers) exceed destructive reef processes (bioerosion and dissolution). In this study, we examine the combined effects of rising ocean acidity and SST on both calcification and dissolution rates of a natural community of secondary calcifiers and bioeroders.

Recent laboratory experiments have focused on the response of individual taxa of bioeroders or secondary calcifiers to climate stressors. For example, studies have specifically addressed the effects of rising ocean acidity and/or temperature on bioerosion by a clionid sponge (Wisshak et al., 2012, 2013; Fang et al., 2013) and a community of photosynthesizing microborers (Tribollet et al., 2009; ReyesNivia et al., 2013). These studies found that bioerosion increased under future climate change scenarios. Several studies have focused on tropical calcifying algae and have found decreased calcification (Semesi et al., 2009; Johnson et al., 2014; Comeau et al., 2013; Jokiel et al., 2008; Kleypas and Langdon, 2006) and increased dissolution (Diaz-Pulido et al., 2012) with increasing ocean acidity and/or SST. However, the bioeroding community is extremely diverse, and can interact with the surrounding community of secondary calcifiers: for example, crustose coralline algae (CCA) can inhibit internal bioerosion (White, 1980; Tribollet and Payri, 2001). To understand the combined response of bioeroders and secondary calcifiers, we take a community perspective and examine the synergistic effects of rising SST and ocean acidity on a natural community of secondary calcifiers and bioeroders. Using the total alkalinity anomaly technique, we test for net changes in calcification during the day and dissolution (most of which is caused by bioeroders; Andersson and Gledhill, 2013) at night. Our climate change treatments are modeled after the Representative Concentration Pathway (RCP) 8.5 climate scenario (Van Vuuren et al., 2011; Meinshausen et al., 2011), one of the high-emission scenarios used in the most recent Intergovernmental Panel on Climate Change (IPCC) report (Cubasch et al., 2013). The RCP 8.5 scenario predicts an increase in temperature of $3.8-5.7^{\circ} \mathrm{C}$ (Rogelj et al., 2012) and an increase in atmospheric $\mathrm{CO}_{2}$ of $557 \mathrm{ppm}$ by the year 2100 (Meinshausen et al., 2011). We use the RCP 8.5 scenario because the current $\mathrm{CO}_{2}$ concentrations are tracking just above what this scenario predicts (Sanford et al., 2014). While prior studies have focused on the contributions of individual community members to increased temper- ature and $\mathrm{CO}_{2}$, here, we examine the community response to the RCP 8.5 climate scenario and measure calcification, dissolution, and net community production rates.

\section{Materials and methods}

\subsection{Collection site}

All collections were made on the windward side of Moku o Lo'e (Coconut Island) in Kaneohe Bay, Hawaii adjacent to the Hawaii Institute of Marine Biology. This fringing reef is dominated by Porites compressa and Montipora capitata, with occasional colonies of Pocillopora damicornis, Fungia scutaria, and Porites lobata. Kaneohe Bay is a protected, semi-enclosed embayment; the residence time can be more than 1 month long in the protected southern portion of the bay (Lowe et al., 2009a, 2009b) that is coupled with a high daily variance in $\mathrm{pH}$ (Guadayol et al., 2014). The wave action is minimal (Smith et al., 1981; Lowe et al., 2009a; Lowe et al., 2009b), and currents are relatively slow $\left(5 \mathrm{~cm} \mathrm{~s}^{-1}\right.$ maximum) and wind driven (Lowe et al., 2009a, 2009b).

\subsection{Sample collection}

We collected pieces of dead Porites compressa coral skeleton (hereafter, referred to as rubble) as representative communities of bioeroders and secondary calcifiers. Rubble was collected with a hammer and chisel from a shallow reef flat ( $\sim 1 \mathrm{~m}$ depth) in November 2012. Only pieces of rubble without any live coral were collected. The rubble community in Kaneohe Bay is comprised of secondary calcifiers, including CCA from the genera Hydrolithon, Sporolithon, and Peyssonnelia, and non-coral calcifying invertebrates (e.g., boring bivalves (Lithophaga fasciola and Barbatia divaricate), oysters (Crassostrea gigas), and small crustaceans), filamentous and turf algae, and internal bioeroders, including boring bivalves ( $L$. fasciola and $B$. divaricate), sipunculids (Aspidosiphon elegans, Lithacrosiphon cristatus, Phascolosoma perlucens, and Phascolosoma stephensoni), phoronids (Phoronis ovalis), sponges (Cliona spp.) and a diverse assemblage of polychaetes (White, 1980). All rubble pieces were combined after collection and maintained in a $100 \mathrm{~L}$ flow-through tank with ambient seawater from Kaneohe Bay until random assignment to treatments.

\subsection{Experimental design}

The Hawaii Institute of Marine Biology (HIMB) hosts a mesocosm facility with flow-through seawater from Kaneohe Bay and controls for light, temperature, $p \mathrm{CO}_{2}$, and flow rate. The facility is comprised of 24 experimental aquaria split between four racks; each rack has a $150 \mathrm{~L}$ header tank that feeds six experimental aquaria, each $50 \mathrm{~L}$ in volume (Fig. 1).

Before adding rubble to the experimental aquaria, we collected day and night samples of $\mathrm{pH}$, total alkalinity (TA), 
Table 1. Means and standard errors of all measured parameters by rack. $p \mathrm{CO}_{2}, \mathrm{HCO}_{3}^{-}, \mathrm{CO}_{3}^{2-}$, DIC, and $\Omega_{\text {arag }}$ were all calculated from the measured TA and $\mathrm{pH}$ samples using $\mathrm{CO}_{2} \mathrm{SYS}$. Each table entry is the mean of 12 water samples: one daytime sample and one nighttime sample for six aquaria within a rack. Data are all from the imposed treatment conditions with no rubble inside the aquaria.

\begin{tabular}{lllll}
\hline Rack & Pre-industrial & Present day & 2050 prediction & 2100 prediction \\
\hline Temp $\left({ }^{\circ} \mathrm{C}\right)$ & $23.8 \pm 0.07$ & $24.8 \pm 0.08$ & $26.2 \pm 0.06$ & $27.2 \pm 0.08$ \\
Salinity & $35.65 \pm 0.01$ & $35.71 \pm 0.02$ & $35.62 \pm 0.02$ & $35.71 \pm 0.02$ \\
$\mathrm{TA}\left(\mu \mathrm{mol} \mathrm{kg}{ }^{-1}\right)$ & $2137 \pm 1.7$ & $2138 \pm 2.3$ & $2139 \pm 2.0$ & $2142 \pm 1.9$ \\
$\mathrm{pH}_{t}$ & $8.02 \pm 0.02$ & $7.87 \pm 0.01$ & $7.74 \pm 0.02$ & $7.67 \pm 0.02$ \\
$p \mathrm{CO}_{2}(\mu \mathrm{atm})$ & $409 \pm 20.0$ & $614 \pm 15.6$ & $868 \pm 33.0$ & $1047 \pm 38.7$ \\
$\left.\mathrm{HCO}_{3}^{-}(\mu \mathrm{mol} \mathrm{kg})^{-1}\right)$ & $1692 \pm 16.9$ & $1815 \pm 7.3$ & $1894 \pm 7.8$ & $1939 \pm 6.6$ \\
$\mathrm{CO}_{3}^{2-}\left(\mu \mathrm{mol} \mathrm{kg}^{-1}\right)$ & $194.20 \pm 6.7$ & $147.08 \pm 2.8$ & $113.98 \pm 3.8$ & $99.24 \pm 3.3$ \\
$\mathrm{DIC}\left(\mu \mathrm{mol} \mathrm{kg}^{-1}\right)$ & $1898 \pm 10.9$ & $1980 \pm 5.1$ & $2032 \pm 5.0$ & $2067 \pm 4.5$ \\
$\Omega_{\mathrm{arag}}$ & $3.06 \pm 0.1$ & $2.32 \pm 0.04$ & $1.80 \pm 0.06$ & $1.57 \pm 0.05$ \\
$\mathrm{NO}_{2}^{-}\left(\mu \mathrm{mol} \mathrm{L}^{-1}\right)$ & $0.082 \pm 0.0028$ & $0.078 \pm 0.0045$ & $0.074 \pm 0.0047$ & $0.070 \pm 0.0051$ \\
$\mathrm{PO}_{4}^{3-}\left(\mu \mathrm{mol} \mathrm{L}^{-1}\right)$ & $0.017 \pm 0.014$ & $0.0097 \pm 0.0081$ & $0.033 \pm 0.016$ & $0.018 \pm 0.0061$ \\
$\mathrm{Si}^{-}(\mathrm{OH})_{4}\left(\mu \mathrm{mol} \mathrm{L}^{-1}\right)$ & $3.60 \pm 0.58$ & $3.64 \pm 0.61$ & $3.88 \pm 0.49$ & $3.78 \pm 0.52$ \\
$\left.\mathrm{NH}_{4}^{+}(\mu \mathrm{mol} \mathrm{L})^{-1}\right)$ & $0.45 \pm 0.30$ & $0.19 \pm 0.067$ & $0.23 \pm 0.15$ & $0.34 \pm 0.14$ \\
$\left.\mathrm{NO}_{3}^{-}(\mu \mathrm{mol} \mathrm{L})^{-1}\right)$ & $2.13 \pm 0.20$ & $2.25 \pm 0.21$ & $2.55 \pm 0.10$ & $2.48 \pm 0.11$ \\
\hline
\end{tabular}

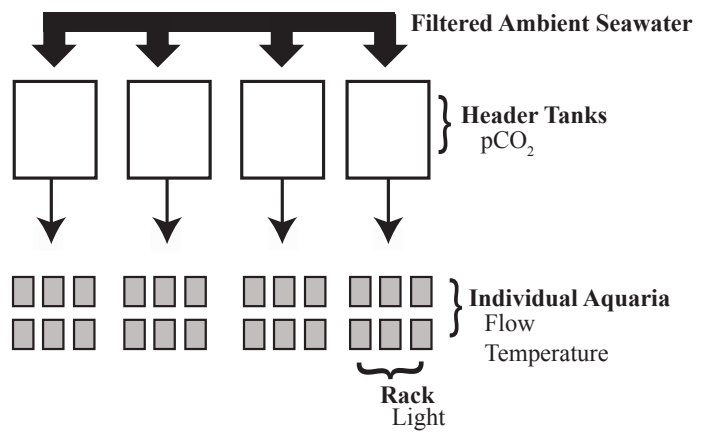

Figure 1. A schematic of the mesocosm system at the Hawaii Institute of Marine Biology. Ambient seawater is pumped into the system from a nearby fringing reef in Kaneohe Bay. The seawater is filtered with a sand trap filter, passed through a water chiller and then fed into one of four header tanks. $p \mathrm{CO}_{2}$ is manipulated in each header tank by bubbling a mixture of $\mathrm{CO}_{2}$-free air and pure $\mathrm{CO}_{2}$ to the desired concentration. The water from one header tank flows into six aquaria (a rack). Light is controlled by a rack with metal-halide lights. There are two metal-halide lights per rack, with each light oscillating over a set of three aquaria. Flow and temperature are controlled in each individual aquarium with flow valves and aquarium heaters and coolers, respectively.

temperature, and salinity from all aquaria to demonstrate the consistency of water conditions across aquaria without any rubble present (Table 1). The long-term temporal stability of the mesocosm system is reported in Putnam (2012). We then conducted "control" and "treatment" experiments to determine how RCP 8.5 predictions affect daytime calcification and nighttime dissolution rates in a natural rubble community. The first "control experiment" characterized baseline calcification and dissolution in each aquarium caused by differences in rubble communities. In the second "treatment experiment", we manipulated $p \mathrm{CO}_{2}$ and temperature to simulate four climate scenarios (pre-industrial, present day, 2050, and 2100) and tested the response of calcification, dissolution, and net community production. Each experiment used the TA anomaly method (Smith and Key, 1975; Andersson et al., 2009). This method calculates net calcification from changes in TA, and calculates net community production from changes in total dissolved inorganic carbon (DIC) adjusted for changes in carbon due to calcificaiton. Because estimates of calcification are based on changes in TA, this method does not account for mechanical erosion (e.g., small chips of $\mathrm{CaCO}_{3}$ produced by sponge erosion). However, given the short duration of the experiment and the types of bioeroders present, we expect that chemical dissolution captured a significant proportion of the erosion in the system.

Approximately $1.2 \mathrm{~L}$ of rubble (3-4 pieces of weight $499 \pm 148 \mathrm{~g}$ and skeletal density $1.53 \pm 0.1 \mathrm{~g} \mathrm{~cm}^{-3}$ (mean $\pm \mathrm{SD}, n=85)$ ) were placed in each of the 24 experimental aquaria and acclimated to tank conditions in ambient seawater for 3 days. On the fourth day, we performed the control experiment, calculating daytime calcification and nighttime dissolution for rubble in ambient seawater conditions using the TA anomaly technique. The next day we manipulated seawater $p \mathrm{CO}_{2}$ and temperature to replicate four climate scenarios for the treatment experiment: pre-industrial $\left(-1 \pm 0.057^{\circ} \mathrm{C}\right.$ and $\left.-205 \pm 11.9 \mu \mathrm{atm}\right)$, present day (natural Kaneohe Bay seawater $24.8 \pm 0.09^{\circ} \mathrm{C}, 614 \pm 15.6 \mu \mathrm{atm}$ ), $2050\left(+1.4 \pm 0.09^{\circ} \mathrm{C}\right.$ and $\left.+255 \pm 31 \mu \mathrm{atm}\right)$, and 2100 $(+2.4 \pm 0.08$ and $+433 \pm 40 \mu \mathrm{atm})$. Note that all changes in temperature and $p \mathrm{CO}_{2}$ were made relative to present-day Kaneohe Bay seawater conditions: $p \mathrm{CO}_{2}$ in Kaneohe Bay 
is consistently high relative to the open ocean and can range from 196 to $976 \mu \mathrm{atm}$ in southern Kaneohe Bay, depending on conditions (Drupp et al., 2013). The yearly average $p \mathrm{CO}_{2}$ at our collection site ranged from 565 to $675 \mu \mathrm{atm}$ (Silbiger et al., 2014). After an acclimation time of 7 days, we sampled the treatment experiment, calculating daytime calcification and nighttime dissolution over a $24 \mathrm{~h}$ period.

During both experiments, TA, $\mathrm{pH}$, salinity, temperature, and dissolved inorganic nutrient (DIN) samples were collected every $12 \mathrm{~h}$ over a $24 \mathrm{~h}$ period: just before lights-on in the morning (time 1) and just before lights-off at night (time 2) to capture light conditions, and then again before lights-on the next morning (time 3 ) to capture dark conditions. Flow into each aquarium was monitored and adjusted every 3 hours to ensure a consistent flow rate over the $24 \mathrm{~h}$ experiment. We calculated net ecosystem calcification and net community production using a simple box model (Andersson et al., 2009) and normalized all our calculations to the surface area of the rubble in each tank. The surface area of the rubble was calculated using the wax dipping technique (Stimson and Kinzie III, 1991) at the end of the experiment.

\subsection{Mesocosm setup}

The mesocosm facility (Fig. 1) is supplied with ambient seawater from Kaneohe Bay, which is filtered through a sand filter, passed through a water chiller (Aqualogic Multi Temp MT-1 model no. 2TTB3024A1000AA), and then fed into one of the four header tanks. $p \mathrm{CO}_{2}$ was manipulated using a $\mathrm{CO}_{2}$ gas blending system (see Fangue et al., 2010; Johnson and Carpenter, 2012). Each target $p \mathrm{CO}_{2}$ concentration was created by mixing $\mathrm{CO}_{2}$-free atmospheric air with pure $\mathrm{CO}_{2}$ using mass flow controllers (C100L Sierra Instruments). Output $p \mathrm{CO}_{2}$ was analyzed using a calibrated infrared $\mathrm{CO}_{2}$ analyzer (A151, Qubit Systems). $\mathrm{CO}_{2}$ mixtures were then bubbled into one of the four header tanks and water from each individual header tank fed into the six individual treatment aquaria (Fig. 1). The $p \mathrm{CO}_{2}$ in each treatment aquarium was estimated with $\mathrm{CO}_{2} \mathrm{SYS}$ (Van Heuven et al., 2011) using $\mathrm{pH}$ and TA as the parameters.

Temperature was manipulated in each treatment aquarium using dual-stage temperature controllers (Aqualogic TR115DN). The temperature was continuously monitored with temperature loggers (TidbiT v2 Water Temperature Data Logger, sampling every $20 \mathrm{~min}$ ), and point measurements were taken during every sampling period with a handheld digital thermometer (Traceable Digital Thermometer, Thermo Fisher Scientific; precision $=0.001{ }^{\circ} \mathrm{C}$ ). Light was controlled by positioning an oscillating pendant metalhalide light $(250 \mathrm{~W})$ over a set of three aquaria and was programmed to emit an equal amount of light to each tank $(\sim 500 \mu \mathrm{E}$ of light). Lights were set to a $12 \mathrm{~h}: 12 \mathrm{~h}$ light to dark photoperiod and were monitored using a LICOR spherical quantum PAR sensor. Flow rate was maintained at $115 \pm 1 \mathrm{~mL} \mathrm{~min}^{-1}$, resulting in a residence time of
$7.3 \pm 0.07 \mathrm{~h}$ per tank. Each aquarium was equipped with a submersible powerhead pump (Sedra KSP-7000 powerhead) to ensure that the tank was well mixed.

\subsection{Seawater chemistry}

All sample collection and storage vials were cleaned in a $10 \% \mathrm{HCl}$ bath for $24 \mathrm{~h}$ and rinsed three times with MilliQ water before use and rinsed three times with sample water during sample collection and processing.

\subsubsection{Total alkalinity}

Duplicate TA samples were collected in $300 \mathrm{~mL}$ borosilicate sample containers with glass stoppers. Each sample was preserved with $100 \mu \mathrm{L}$ of $50 \%$ saturated $\mathrm{HgCl}_{2}$ and analyzed within 3 days using open cell potentiometric titrations on a Mettler T50 autotitrator (Dickson et al., 2007). A certified reference material (CRM - Reference Material for Oceanic $\mathrm{CO}_{2}$ Measurements, A. Dickson, Scripps Institution of Oceanography) was run at the beginning of each sample set. The accuracy of the titrator never deviated more than $\pm 0.8 \%$ from the standard, and TA measurements were corrected for these deviations. The precision was $3.55 \mu \mathrm{Eq}$ (measured as the standard deviation of the duplicate water samples). During the $24 \mathrm{~h}$ control experiment, the average changes in TA were $37 \mu \mathrm{Eq}$ over the day and $20 \mu \mathrm{Eq}$ over the night (day and night TA changes were of a larger magnitude in the treatment experiments): these are measurable changes given the precision and accuracy of the TA measurements.

\subsection{2 $\mathrm{pH}_{t}$ (total scale)}

Duplicate $\mathrm{pH}_{t}$ samples were collected in $20 \mathrm{~mL}$ borosilicate glass vials, brought to a constant temperature of $25^{\circ} \mathrm{C}$ in a water bath, and immediately analyzed using an m-cresol dye addition spectrophotometric technique (Dickson et al., 2007). The accuracy of the $\mathrm{pH}$ was tested against a Tris buffer of known $\mathrm{pH}_{t}$ from the Dickson Lab at the Scripps Institution of Oceanography (Dickson et al., 2007). Our accuracy was better than $\pm 0.04 \%$, and the precision was $0.004 \mathrm{pH}$ units (measured as the standard deviation of the duplicate water samples). In situ $\mathrm{pH}$ and the remaining carbonate parameters were calculated using $\mathrm{CO}_{2} \mathrm{SYS}$ (Van Heuven et al., 2011) with the following measured parameters: $\mathrm{pH}_{t}, \mathrm{TA}$, temperature, and salinity. The K1K2 apparent equilibrium constants were from Mehrbach (1973) and refit by Dickson and Millero (1987), and $\mathrm{HSO}_{4}^{-}$dissociation constants were taken from Uppström (1974) and Dickson (1990).

\subsubsection{Salinity}

Duplicate salinity samples were analyzed on a Portasal 8410 portable salinometer calibrated with an OSIL IAPSO standard (accuracy $= \pm 0.003$, precision $= \pm 0.0003$ ). 


\subsubsection{Nutrients}

Nutrient samples were collected with $60 \mathrm{~mL}$ plastic syringes and immediately filtered through combusted $25 \mathrm{~mm}$ glass fiber filters $(\mathrm{GF} / \mathrm{F} 0.7 \mu \mathrm{m})$ and transferred into $50 \mathrm{~mL}$ plastic centrifuge tubes. Nutrient samples were frozen and later analyzed for $\mathrm{Si}(\mathrm{OH})_{4}, \mathrm{NO}_{3}^{-}, \mathrm{NO}_{2}^{-}, \mathrm{NH}_{4}^{+}$, and $\mathrm{PO}_{4}^{3-}$ on a Seal Analytical AA3 HR Nutrient Analyzer at the UH SOEST Lab for Analytical Chemistry.

\subsection{Measuring net ecosystem calcification}

We assumed that the mesocosms were well-mixed systems; thus, we calculated net ecosystem calcification and net community photosynthesis following the simple box model presented in Andersson et al. (2009). TA was normalized to a constant salinity (35) to account for changes due to evaporation and then corrected for dissolved inorganic nitrogen and phosphate to account for their small contributions to the acid-base system (Wolf-Gladrow et al., 2007). Net ecosystem calcification, or $G$, was calculated using the following equation:

$G=\left[F_{\mathrm{TAin}}-F_{\mathrm{TAout}}-\frac{\mathrm{dTA}}{\mathrm{d} t}\right] / 2$,

where $F_{\mathrm{TAin}}$ is the rate of TA flowing into an aquarium (the average TA in the header tank times the inflow rate), $F_{\text {TAout }}$ is the rate of TA flowing out of an aquarium (the average TA in the aquarium times the outflow rate), and, $\frac{\mathrm{dTA}}{\mathrm{d} t}$ is the change in TA in an aquarium during the measurement period (change in TA normalized to the volume of water and the surface area of the rubble); specific calculations are given in the supplemental material. The equation is divided by 2 because 1 mole of $\mathrm{CaCO}_{3}$ is precipitated or dissolved for every 2 moles of TA removed or added to the water column. Here, $G$ represents the sum of all the calcification processes minus the sum of all the dissolution processes in $\mathrm{mmol} \mathrm{CaCO}_{3} \mathrm{~m}^{-2} \mathrm{~h}^{-1}$; thus, all positive numbers are net calcification, and all negative numbers are negative net calcification (i.e., net dissolution). Net daytime calcification $\left(G_{\text {day }}\right)$ is calculated from the first $12 \mathrm{~h}$ sampling period in the light, net nightime dissolution $\left(G_{\text {night }}\right)$ is calculated from the second $12 \mathrm{~h}$ sampling period in the dark, and total net calcification $\left(G_{\text {net }}\right)$ is calculated from the full $24 \mathrm{~h}$ cycle $\left(G_{\text {day }}+G_{\text {night }}\right) . G_{\text {day }}, G_{\text {night }}$, and $G_{\text {net }}$ are converted from hourly to daily rates and presented as mmol $\mathrm{CaCO}_{3} \mathrm{~m}^{-2} \mathrm{~d}^{-1}$.

\subsection{Measuring net community production and respiration}

Net community production (NCP) was calculated by measuring changes in DIC (Gattuso et al., 1999). DIC was normalized to a constant salinity (35) to account for any evaporation over the $24 \mathrm{~h}$ period. We used a simple box model to calculate
NCP:

$\mathrm{NCP}=\left[F_{\text {DICin }}-F_{\text {DICout }}-\frac{\mathrm{dDIC}}{\mathrm{d} t}\right]-G$.

$F_{\text {DICin }}, F_{\text {DICout }}$, and $\frac{\mathrm{dDIC}}{\mathrm{d} t}$ are the rates of DIC flowing into the aquaria, flowing out of the aquaria, and the change in DIC in the aquaria per unit time in $\mathrm{mmol} \mathrm{C} \mathrm{m}^{-2} \mathrm{~h}^{-1}$, respectively. To measure NCP, we subtract $G$ to remove any change in carbon due to inorganic processes. NCP represents the sum of all the photosynthetic processes minus the sum of all the respiration processes; thus, all positive numbers are net photosynthesis and all negative numbers are negative net photosynthesis (i.e., net respiration). Net daytime $\mathrm{NCP}\left(\mathrm{NCP}_{\text {day }}\right)$ is calculated from the first $12 \mathrm{~h}$ sampling period in the light, net nightime $\mathrm{NCP}\left(\mathrm{NCP}_{\text {night }}\right)$ is calculated from the second $12 \mathrm{~h}$ sampling period in the dark, and total $\mathrm{NCP}\left(\mathrm{NCP}_{\text {net }}\right)$ is calculated from the full $24 \mathrm{~h}$ cycle $\left(\mathrm{NCP}_{\text {day }}+\mathrm{NCP}_{\text {night }}\right)$. All rates are presented as mmol $\mathrm{Cm}^{-2} \mathrm{~d}^{-1}$.

\subsection{Statistical analysis}

Each aquarium contained a slightly different rubble community because of the randomization of rubble pieces to each treatment. To ensure there were no systematic differences in rubble communities between racks (rack effects) before the experimental treatments were applied, we tested for differences in calcification and NCP between racks in the control experiment using an ANOVA (Fig. S2 in the Supplement).

In the treatment experiment, we first tested for feedbacks in carbonate chemistry due to the presence of rubble: using a paired $t$ test, we compared the day-night difference in measured $p \mathrm{CO}_{2}$ in each aquarium with rubble, $\left(p \mathrm{CO}_{2} \text {, day }-p \mathrm{CO}_{2} \text {, night }\right)_{\text {rubble, }}$, and without rubble, $\left(p \mathrm{CO}_{2, \text { day }}-p \mathrm{CO}_{2, \text { night }}\right)_{\text {no rubble }}$.

Although we imposed four discrete temperature- $p \mathrm{CO}_{2}$ scenario treatments on each tank (Table 1), random variation between treatments and the feedback between the rubble communities and the water chemistry resulted in nearcontinuous variation in temperature- $p \mathrm{CO}_{2}$ treatments across aquaria (Figs. 2 and $\mathrm{S} 1$ in the Supplement). To capture this continuous variation in temperature- $-p \mathrm{CO}_{2}$ in the analysis, we used the measured temperature- $p \mathrm{CO}_{2}$ seawater condition as a continuous independent variable in a regression rather than the four categorical treatment conditions in an ANOVA (an analysis of $G$ and NCP using the ANOVA approach is included in Figs. S3, S4 and Tables S1, S2 in the Supplement). The regression approach allowed us to capture the quantitative relationships better between net calcification $(G)$ or NCP and the temperature $-p \mathrm{CO}_{2}$ treatment. We created a single, continuous variable, standardized climate change (SCC), from a linear combination of temperature and $p \mathrm{CO}_{2}$ values in each aquarium. A simple linear combination was used because $p \mathrm{CO}_{2}$ increased linearly with temperature (Fig. 2), as imposed by our treatments. We first calculated the relationship between $\Delta$ Temp (Eq. 3) and $\Delta p \mathrm{CO}_{2}$ (Eq. 4) 
Table 2. Regression results for the treatment experiments: $G_{\text {day }}$, $G_{\text {night }}$, and $G_{\text {net }}$ versus standardized climate change (Fig. 3a, c, e) and $\mathrm{NCP}_{\text {day }}, \mathrm{NCP}_{\text {night }}$, and $\mathrm{NCP}_{\text {net }}$ versus standardized climate change (Fig. 3b, d, f). Bold values indicate a statistically significant $p$ value at $\alpha<0.05$.

\begin{tabular}{lrrrrr}
\hline & SS & $\mathrm{d} f$ & $F$ & $p$ & $R^{2}$ \\
\hline$G_{\text {day }}$ & & & & & \\
Standardized climate change & 3.79 & 1 & 1.45 & 0.06 & \\
(Standardized climate change) $^{2}$ & 23.63 & 1 & 9.04 & $\mathbf{0 . 0 0 7}$ & \\
Error & 54.89 & 21 & & & 0.33 \\
\hline$G_{\text {night }}$ & & & & & \\
Standardized climate change & 67.80 & 1 & 39.14 & $<\mathbf{0 . 0 0 0 1}$ & \\
Error & 38.11 & 22 & & & 0.64 \\
\hline$G_{\text {net }}$ & & & & & \\
Standardized climate change & 88.01 & 1 & 19.49 & $<\mathbf{0 . 0 0 1}$ & \\
Error & 99.35 & 22 & & & 0.47 \\
\hline NCP & & & & & \\
Standardized climate change & 5687.2 & 1 & 57.36 & $<\mathbf{0 . 0 0 0 1}$ & \\
Error & 2181.4 & 22 & & & 0.72 \\
\hline NCP $_{\text {night }}$ & & & & & \\
Standardized climate change & 3816.1 & 1 & 52.06 & $<\mathbf{0 . 0 0 0 1}$ & \\
Error & 1612.6 & 22 & & & 0.70 \\
\hline NCP $_{\text {net }}$ & & & & & \\
Standardized climate change & 17925 & 1 & 121.47 & $<\mathbf{0 . 0 0 0 1}$ & \\
Error & 3246.4 & 22 & & & 0.85 \\
\hline
\end{tabular}

using linear regression. The coefficients from this regression (slope: $\alpha=0.0031 ; y$ intercept: $\beta=-0.078$ ) were used to combine $p \mathrm{CO}_{2}$ and temperature onto the same scale, as a measure of standardized climate change (Eq. 5):

$\Delta \mathrm{Temp}_{i}=\mathrm{Temp}_{\mathrm{trt}, i}-\mathrm{Temp}_{\mathrm{cont}, i}$,
$\Delta p \mathrm{CO}_{2_{i}}=p \mathrm{CO}_{2_{\mathrm{tr}, i}}-p \mathrm{CO}_{2_{\mathrm{cont}, i}}$,
$\mathrm{SCC}_{i}=\Delta \mathrm{Temp}_{i}+\alpha \cdot \Delta p \mathrm{CO}_{2_{i}}+\beta$.

This synthetic temperature- $p \mathrm{CO}_{2}$ axis, $\mathrm{SCC}$, is centered on the ambient (control) conditions such that a value of 0 corresponds to present-day Kaneohe Bay conditions, a negative value corresponds to water that is colder and less acidic (pre-industrial) and a positive value corresponds to water that is warmer and more acidic (future conditions) compared to background seawater. (The independent relationships between $G$ and NCP with $\Delta$ Temp and $\Delta p \mathrm{CO}_{2}$ are shown in Figs. S5 and S6 in the Supplement and are similar to the relationship with SCC.)

With SCC as a continuous, independent variable, we used a regression to test for linear and nonlinear relationships between day, night, and net calcification $\left(G_{\text {day }}, G_{\text {night }}\right.$, and $\left.G_{\text {net }}\right)$ and $\mathrm{NCP}\left(\mathrm{NCP}_{\text {day }}, \mathrm{NCP}_{\text {night }}\right.$, and $\left.\mathrm{NCP}_{\text {net }}\right)$ versus SCC. For a simple test of nonlinearity in the response of calcification to SCC, we included a quadratic term $\left(\mathrm{SCC}^{2}\right)$ in the model. For $G_{\text {day }}$, we used weighted regression (weight function: $w_{i}=1 /\left(1+\left|r_{i}\right|\right)$ ), where $w_{i}=$ weight and $r_{i}=$ residual, Fair, 1974) to account for heteroscedasticity. All other data met assumptions for a linear regression. Lastly, we used a linear regression to test the relationship between $G$ and NCP.
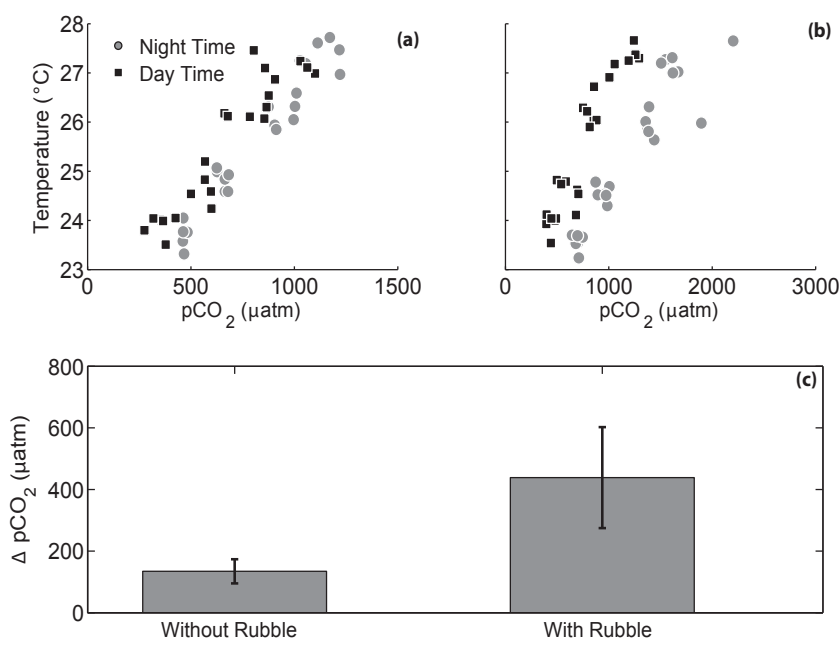

Figure 2. $p \mathrm{CO}_{2}$ and temperature in each aquarium (a) without any rubble present and (b) with rubble present. Daily variability in $p \mathrm{CO}_{2}$ was higher when rubble was present due to feedbacks from the rubble community (note the different $x$ axis scales in panels (a) and (b)). Panel (c) shows the mean difference between day and night $p \mathrm{CO}_{2}$ with and without rubble present, with observations paired by aquarium (error bars are standard error) $\left(t_{23}=-7.23, p<0.0001\right)$.

\section{Results}

\subsection{Control experiment}

For rubble in ambient seawater conditions, the average $G_{\text {day }}, G_{\text {night }}$, and $G_{\text {net }}$ in the control experiment were $3.4 \pm 0.16 \mathrm{mmol} \mathrm{m}^{-2} \mathrm{~d}^{-1},-2.4 \pm 0.15 \mathrm{mmol} \mathrm{m}^{-2} \mathrm{~d}^{-1}$, and $0.96 \pm 0.20 \mathrm{mmol} \mathrm{m}^{-2} \mathrm{~d}^{-1}$, respectively. There was no significant difference in $G_{\text {day }}\left(F_{3,23}=0.68, p=0.58\right)$, $G_{\text {night }}$ $\left(F_{3,23}=1.52, p=0.24\right)$, or $G_{\text {net }}\left(F_{3,23}=1.38, p=0.28\right)$ between racks in the control experiment (Fig. S2). NCP rates also did not show any rack effects. Average NCP rates were $23.2 \pm 1.4 \mathrm{mmol} \mathrm{m}^{-2} \mathrm{~d}^{-1} \quad\left(F_{3,23}=0.07, \quad p=0.94\right)$ during the day, $-20.7 \pm 1.9 \mathrm{mmol} \mathrm{m}^{-2} \mathrm{~d}^{-1}\left(F_{3,23}=1.95\right.$, $p=0.15)$ during the night, and $2.5 \pm 2.1 \mathrm{mmol} \mathrm{m}^{-2} \mathrm{~d}^{-1}$ $\left(F_{3,23}=1.5, p=0.25\right)$ over the entire $24 \mathrm{~h}$ period.

\subsection{Treatment experiment}

The rubble communities significantly altered the seawater chemistry, with higher $p \mathrm{CO}_{2}$ than the applied $p \mathrm{CO}_{2}$ manipulation, particularly at night (Fig. S1). The mean difference between day and night $p \mathrm{CO}_{2}$ for all treatments was $134.4 \pm 39 \mu \mathrm{atm}$ without rubble and was $438.5 \pm 163.9 \mu \mathrm{atm}$ when rubble was present $\left(t_{23}=-7.23, p<0.0001\right.$; Fig. 2$)$. 

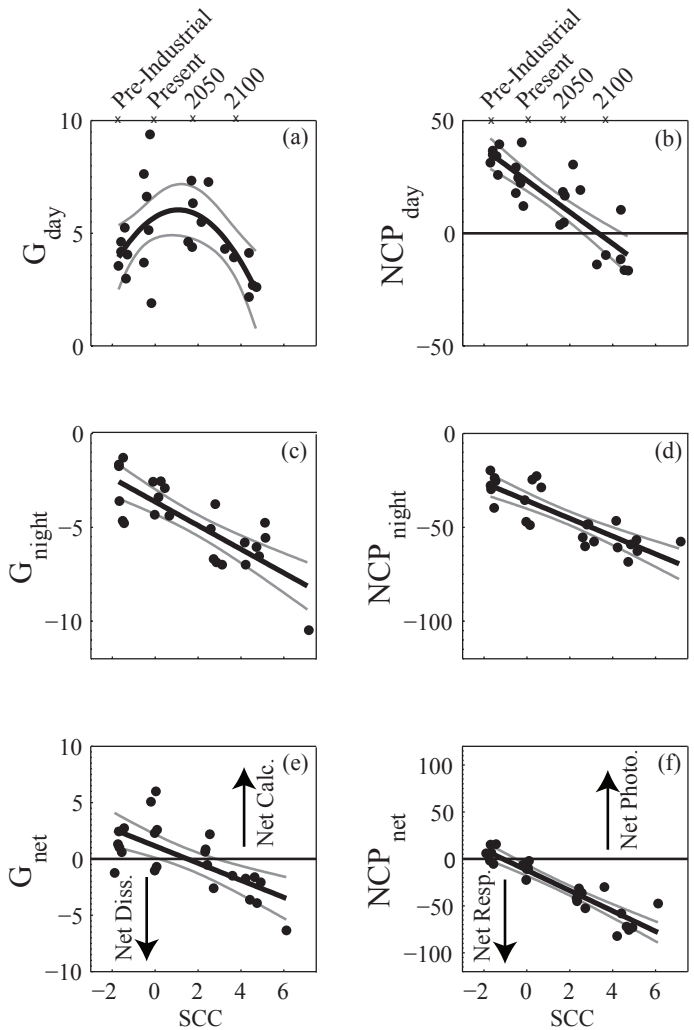

Figure 3. Net ecosystem calcification ((a) $G_{\text {day }}$, (c) $G_{\text {night }}$, (e) and $G_{\text {net }}$ ) and net community production ((b) $\mathrm{NCP}_{\text {day }}$, (d) $\mathrm{NCP}_{\text {night }}$, and (f) $\mathrm{NCP}_{\text {net }}$ ) versus standardized climate change (SCC). Each point represents net ecosystem calcification (left panel) or net community production (right panel) calculated from an individual aquarium. Standardized climate change was centered around background seawater conditions such that a value of 0 indicated that there was no change in $p \mathrm{CO}_{2}$ or temperature. Positive values indicate an elevated $p \mathrm{CO}_{2}$ and temperature condition relative to background, and negative values represent lower $p \mathrm{CO}_{2}$ and temperature conditions. $G_{\text {day }}$ had a non-linear relationship with standardized climate change $\left(y=-0.27 x^{2}+0.59 x+5.7\right)$, while $G_{\text {night }}$ $(y=-0.63 x-3.6)$ and $G_{\text {net }}(y=-0.76 x+1.1)$ each had a negative linear relationship with standardized climate change (Table 2). $\mathrm{NCP}_{\text {day }}(y=-7.01 x+23.4), \mathrm{NCP}_{\text {night }}(y=-35.76-4.74)$, and $\mathrm{NCP}_{\text {net }}(y=-12.07 x-10.85)$ all had significant negative relationships with standardized climate change. Black lines are best fit lines for each model with $95 \%$ confidence intervals in gray. The $x$ 's in the top panel represent the imposed conditions for pre-industrial, present day, 2050, and 2100. The black horizontal line in panels (b), (e) and (f) shows the point where $G$ and NCP equal 0. Points above the line are net calcifying (e) or net photosynthesizing (f) and points below the line are net dissolving (e) or net respiring (f) over the entire $24 \mathrm{~h}$ period.

Standardized climate change was a significant predictor for $G_{\text {day }}, G_{\text {night }}$, and $G_{\text {net }}$ (Table 2; Fig. 3). $G_{\text {day }}$ had a nonlinear relationship with standardized climate change (Table 2, Fig. 3a), increasing to a threshold and then rapidly declining. $G_{\text {night }}$, however, had a strong linear relationship
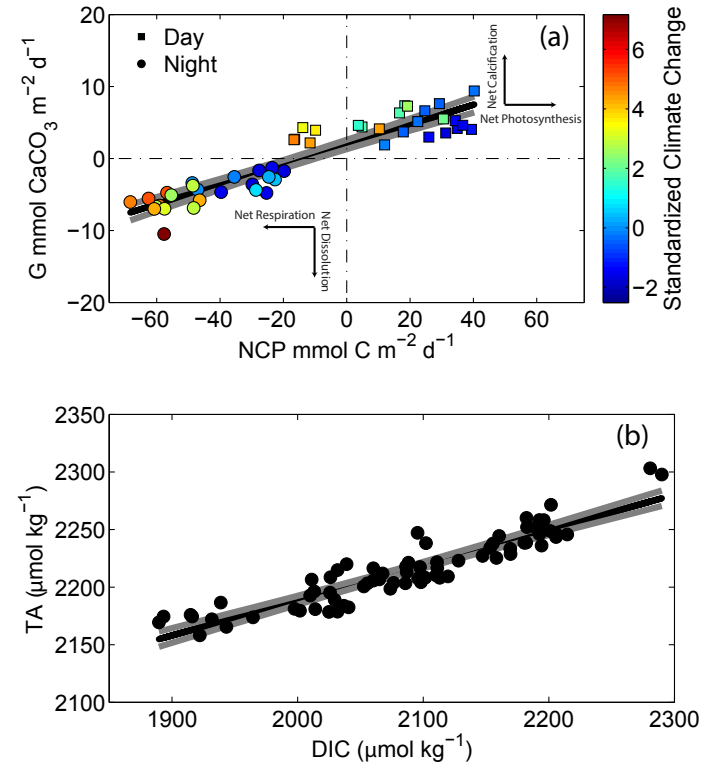

Figure 4. (a) Calculated $G$ and NCP rates for all treatment aquaria. Squares are data collected during light (day) conditions and circles represent data collected during dark (night) conditions, and the color represents standardized climate change (color bar). There is a strong positive relationship between $G$ and NCP $(y=0.14 x+1.9$, $\left.p<0.0001, R^{2}=0.85\right)$. Negative and positive $y$ values are net dissolution and net calcification, respectively; negative and positive $x$ values are net respiration and net photosynthesis, respectively. (b) TA versus DIC: There is a strong positive relationship between TA and DIC $\left(y=0.31 x+1577.4, p<0.0001, R^{2}=0.85\right)$. Black and gray lines represent the best-fit line and $95 \%$ confidence intervals, respectively. As expected, the slope of TA versus DIC (0.31) is approximately twice that of $G$ versus NCP $(0.14)$.

with standardized climate change (Table 2; Fig. 3c), suggesting that joint increases in ocean $p \mathrm{CO}_{2}$ and temperature will increase nighttime dissolution of coral rubble. Lastly, $G_{\text {net }}$ had a strong negative relationship with standardized climate change (Table 2; Fig. 3e), and the rubble community switched from net calcification to net dissolution at an increase in $p \mathrm{CO}_{2}$ and temperature of $271 \mu \mathrm{atm}$ and $0.75^{\circ} \mathrm{C}$, respectively. Standardized climate change was also a significant predictor of NCP: day, night, and net NCP rates all declined with standardized climate change (Table 2; Fig. 3b, d, f).

Net ecosystem calcification increased with net community production $\left(F_{1,46}=260, p<0.0001, R^{2}=0.85\right.$; Fig. 4$)$. In general, communities were net photosynthesizing and net calcifying during the day (Fig. 4a: squares in the upper right quadrant) and were net respiring and net dissolving at night (Fig. 4a: circles in the lower left quadrant). The exceptions were communities in the most extreme temperature- $p \mathrm{CO}_{2}$ treatment: these communities were net respiring during the day while holding a positive, yet very low, calcification rate (Fig. 4a: squares in the upper left quadrant). 


\section{Discussion}

\subsection{Carbonate chemistry feedbacks}

The rubble communities in the aquaria significantly altered the seawater chemistry, particularly at night $\left(t_{23}=-7.23\right.$, $p<0.0001$; Figs. 2, S1). This day-night difference in seawater chemistry increased under more extreme climate scenarios, as predicted by Jury et al. (2013). This large diel swing in $p \mathrm{CO}_{2}$ is not uncommon in shallow coral reef environments. $p \mathrm{CO}_{2}$ ranged from 480 to $975 \mu \mathrm{atm}$ over $24 \mathrm{~h}$ on a shallow reef flat adjacent to our collection site (Silbiger et al., 2014) and from 450 to $742 \mu \mathrm{atm}$ on a Moloka 'i reef flat dominated by coral rubble (Yates and Halley, 2006). Here, $p \mathrm{CO}_{2}$ had an average difference of $438 \mu \mathrm{atm}$ between day and night, with a range of $412 \mu \mathrm{atm}$ in the pre-industrial treatment to $854 \mu \mathrm{atm}$ in the most extreme temperature $-p \mathrm{CO}_{2}$ treatments (Fig. 2). In our study, we incorporated these feedbacks into the statistical analysis by using the actual, sampled $p \mathrm{CO}_{2}$ (and temperature) in each aquarium (Fig. 3) rather than using the intended $p \mathrm{CO}_{2}$ (and temperature) treatments in an ANOVA (Tables S1, S2 and Figs. S3, S4), better reflecting the $p \mathrm{CO}_{2}$ experienced by organisms in each aquarium.

\subsection{Calcification, dissolution, and net community production in a high $\mathrm{CO}_{2}$ and temperature environment}

Our results suggest that as $p \mathrm{CO}_{2}$ and temperature increase over time, rubble reefs may shift from net calcification to net dissolution. In our study, this tipping point occurred at a $p \mathrm{CO}_{2}$ and temperature increase of $271 \mu \mathrm{atm}$ and $0.75^{\circ} \mathrm{C}$. Furthermore, our results showed that $G_{\text {day }}$ and $G_{\text {night }}$ in a natural coral rubble community have different functional responses to changing $p \mathrm{CO}_{2}$ and temperature (Fig. 3). The ranges in $G_{\text {day }}$ and $G_{\text {night }}$ in our aquaria were similar to in situ rates on Hawaiian rubble reefs. Yates and Halley (2006) saw $G_{\text {day }}$ values between 3.3 and $11.7 \mathrm{mmol} \mathrm{CaCO}_{3} \mathrm{~m}^{-2} \mathrm{~d}^{-1}$ and $G_{\text {night }}$ values between -2.4 and $-24 \mathrm{mmol} \mathrm{CaCO}_{3} \mathrm{~m}^{-2} \mathrm{~d}^{-1}$ on a Moloka'i reef flat with coral rubble only (note that Yates and Halley calculated $G$ over a $4 \mathrm{~h}$ time frame and that the data were multiplied by 3 here to show $G$ in $\mathrm{mmol} \mathrm{m}^{-2} \mathrm{~d}^{-1}$ ). Also note that we normalized our rates to the surface area of the rubble, while Yates and Halley (2006) normalized their rates to planar surface area.). $G_{\text {day }}$ and $G_{\text {night }}$ in our experiment ranged from 1.9 to 9.4 and -1.3 to $-10.5 \mathrm{mmol} \mathrm{CaCO}_{3} \mathrm{~m}^{-2} \mathrm{~d}^{-1}$, respectively, across all treatment conditions. The higher dissolution rates in the in situ study by Yates and Halley (2006) are likely due to dissolution in the sediment, which was not present in our study.

$G_{\text {day }}$ had a non-linear response to standardized climate change. $G_{\text {day }}$ increased with temperature- $-p \mathrm{CO}_{2}$ until slightly above ambient conditions, and then decreased under more extreme climate conditions (Fig. 3a). This mixed response, increasing and then decreasing with standardized climate change, is reflected in prior experiments. We suggest three possible mechanisms to explain why calcification increases in slightly higher temperature- $p \mathrm{CO}_{2}$ than ambient conditions. (1) Some calcifiers can maintain and even increase their calcification rates in acidic conditions (Kamenos et al., 2013; Findlay et al., 2011; Rodolfo-Metalpa et al., 2011; Martin et al., 2013) by either modifying their local pH environment (Hurd et al., 2011) or partitioning their energetic resources towards calcification (Kamenos et al., 2013). For example, in low, stable $\mathrm{pH}$ conditions, the coralline algae, Lithothamnion glaciale, increased its calcification rate relative to a control treatment, but did not concurrently increase its rate of photosynthesis (Kamenos et al., 2013). Kamenos et al. (2013) suggest that the up-regulation of calcification may limit photosynthetic efficiency. In the present study, the increase in $G_{\text {day }}$ coincided with a decrease in net photosynthesis (Fig. 3a, b). Photosynthesizing calcifiers in the community may be partitioning their energetic resources more towards calcification and away from photosynthesis in order to maintain a positive calcification rate (Kamenos et al., 2013). Notably, turf algae likely have a major control over the NCP in this community, which would not have any impact on calcification. (2) An alternative hypothesis is that the calcifiers may be adapted or acclimatized to high $p \mathrm{CO}_{2}$ conditions (Johnson et al., 2014) and have not yet reached their threshold because the rubble was collected from a naturally high and variable $p \mathrm{CO}_{2}$ environment (Guadayol et al., 2014; Silbiger et al., 2014). (3) In this study, the calcifiers experienced a combined increase in both $p \mathrm{CO}_{2}$ and temperature and, thus, the non-linear response in $G_{\text {day }}$ may also be due a metabolic response. In a typical thermal performance curve, organisms increase their metabolism until they have reached a thermal maximum, and then rapidly decline (Huey and Kingsolver, 1989; Pörtner et al., 2006), and we see this response in our results. A recent study found a similar non-linear response to temperature and $p \mathrm{CO}_{2}$ in the coral Siderastrea sidera (Castillo et al., 2014). While they attribute the $p \mathrm{CO}_{2}$ response to photosynthesis being neutralized (we did not see this response in our non-coral community), they suggest that the thermal response is due to both changes in metabolism and thermally driven changes in the aragonite saturation state (Castillo et al., 2014).

We saw a decline in both calcification and NCP in the extreme temperature- $p \mathrm{CO}_{2}$ condition (Fig. 3). Calcification has been shown to decline with climate stressors, and the magnitude of decline differs across species (Kroeker et al., 2010; Pandolfi et al., 2011; Ries et al., 2009; Kroeker et al., 2013). The concurrent decline in NCP and calcification (Figs. 3a, b and 4) suggests that non-photosynthesizing invertebrates in the community (such as bivalves) might be dominating the calcification signal in these conditions. This hypothesis would explain the pattern that we see in Fig. 4, where communities in the most extreme $p \mathrm{CO}_{2}$ and temperature conditions are net respiring during the day while still 
maintaining a small, positive calcification rate (Fig. 4a: five points in the upper left quadrant).

$G_{\text {night }}$ rates are more straightforward, decreasing linearly with $p \mathrm{CO}_{2}$ and temperature (Figs. $3 \mathrm{c}$ and 4). $\mathrm{NCP}_{\text {night }}$ rates also decreased linearly with $p \mathrm{CO}_{2}$ and temperature (Fig. 3d). Similarly, Andersson et al. (2009) saw an increase in dissolution under acidic conditions in a community of corals, sand, and CCA. Previous studies on individual bioeroder taxa have also found higher rates of bioerosion or dissolution in more acidic, higher-temperature conditions (Wisshak et al., 2013; Fang et al., 2013; Reyes-Nivia et al., 2013; Tribollet et al., 2009; Wisshak et al., 2012). There are several mechanisms that could be mediating the increased dissolution rates in the high temperature $-p \mathrm{CO}_{2}$ treatments. (1) Higher temperatures could increase the metabolism of the bioeroder community, thus increasing borer activity (e.g., Davidson et al., 2013). (2) Because many boring organisms excrete acidic compounds to erode the skeletal structure (Hutchings, 1986), reduced pH in the overlaying water column may reduce the metabolic cost to the organisms, making it easier for eroders to break down the $\mathrm{CaCO}_{3}$. (3) Higher dissolution rates could be mediated by an increase in the proportion of dolomite in the skeletal structure of CCA on the rubble. A recent study found a $200 \%$ increase in dolomite in CCA that were exposed to high $p \mathrm{CO}_{2}$ and temperature conditions; this increase in dolomite resulted in increased bioerosion by endolithic algae (DiazPulido et al., 2014). However, it is unlikely that changes in the mineralogy of the CCA indirectly increased dissolution here, given the short timescale of our study. In the present study, we used the TA anomaly method to calculate chemical dissolution as a proxy for bioerosion. Future studies should also include measures of mechanical breakdown (e.g. the production of sponge chips) in addition to chemical dissolution for a more complete picture of the impacts of climate stress on reef breakdown. Studies, including the present one, which focused on community-level responses, have consistently found that ocean acidification will increase dissolution rates on coral reefs (Andersson and Gledhill, 2013).

Standardized climate change explained more of the variance in dissolution than in calcification in our rubble community $\left(R_{G_{\text {night }}}^{2}=0.64>R_{G_{\text {day }}}^{2}=0.33\right.$; Table 2$)$. This result is not surprising. Bioerosion, an important driver of dissolution, may be more sensitive to changes in ocean acidity than calcification, leading to net dissolution in high $\mathrm{CO}_{2}$ waters. Many boring organisms excrete acidic compounds, which may be less metabolically costly in a low pH environment. Erez et al. (2011) hypothesize that increased dissolution, rather than decreased calcification, maybe be the reason that net coral reef calcification is sensitive to ocean acidification. The results of this study support this hypothesis. Although $G_{\text {net }}$ declines linearly with temperature $-p \mathrm{CO}_{2}$, calcification $\left(G_{\text {day }}\right)$ and dissolution $\left(G_{\text {night }}\right)$ have distinct responses to standardized climate change: $G_{\text {day }}$ had a non-linear response, while $G_{\text {night }}$ declined linearly with standardized climate change.
Our results highlight the need to study the effects of climate stressors on both calcification and dissolution.

\section{The Supplement related to this article is available online at doi:10.5194/bg-12-567-2015-supplement.}

Author contributions. Conceived and designed the experiments: N. J. Silbiger, M. J. Donahue. Performed the experiments: N. J. Silbiger. Analyzed the data: N. J. Silbiger, M. J. Donahue. Wrote the paper: N. J. Silbiger, M. J. Donahue.

Acknowledgements. Thanks to I. Caldwell, R. Coleman, J. Faith, K. Hurley, J. Miyano, R. Maguire, D. Schar, J. M. Sziklay, and M. M. Walton for help in field collections and lab analyses and to R. Briggs from UH SOEST Lab for Analytical Chemistry. M. J. Atkinson, R. Gates, C. Jury, H. Putnam, and R. Toonen gave thoughtful advice throughout the project. Comments by F. Mackenzie and our two anonymous reviewers improved this manuscript. This project was supported by a NOAA Nancy Foster Scholarship to N. J. Silbiger, a PADI Foundation Grant to N. J. Silbiger, and Hawaii SeaGrant 1847 to M. J. Donahue. This paper is funded in part by a grant/cooperative agreement from the National Oceanic and Atmospheric Administration, Project R/IR-18, which is sponsored by the University of Hawaii Sea Grant College Program, SOEST, under Institutional Grant No. NA09OAR4170060 from the NOAA Sea Grant Office, Department of Commerce. The views expressed herein are those of the author(s) and do not necessarily reflect the views of NOAA or any of its subagencies. This is HIMB contribution no. 1607, Hawaii SeaGrant contribution no. UNIHI-SEAGRANT-JC-12-19, and SOEST contribution no. 9237.

Edited by: J. Middelburg

\section{References}

Adey, W. H.: Review - coral reefs: algal structures and mediated ecosystems in shallow turbulent, alkaline waters, J. Phycol., 34, 393-406, 1998.

Andersson, A. J. and Gledhill, D.: Ocean Acidification and Coral Reefs: Effects on Breakdown, Dissolution, and Net Ecosystem Calcification, Ann. Rev. Mar. Sci., 5, 321-348, 2013.

Andersson, A. J. and Mackenzie, F. T.: Revisiting four scientific debates in ocean acidification research, Biogeosciences, 9, 893905, doi:10.5194/bg-9-893-2012, 2012.

Andersson, A. J., Kuffner, I. B., Mackenzie, F. T., Jokiel, P. L., Rodgers, K. S., and Tan, A.: Net Loss of $\mathrm{CaCO}_{3}$ from a subtropical calcifying community due to seawater acidification: mesocosm-scale experimental evidence, Biogeosciences, 6, 1811-1823, doi:10.5194/bg-6-1811-2009, 2009.

Andersson, A. J., Mackenzie, F. T., and Gattuso, J.-P.: Effects of ocean acidification on benthic processes, organisms, and ecosystems, in: Ocean Acidification, edited by: Gattuso, J.-P. and Hansson, L., Oxford University Press, 122-153, 2011. 
Bopp, L., Resplandy, L., Orr, J. C., Doney, S. C., Dunne, J. P., Gehlen, M., Halloran, P., Heinze, C., Ilyina, T., Séférian, R., Tjiputra, J., and Vichi, M.: Multiple stressors of ocean ecosystems in the 21st century: projections with CMIP5 models, Biogeosciences, 10, 6225-6245, doi:10.5194/bg-10-6225-2013, 2013.

Caldeira, K. and Wickett, M. E.: Oceanography: anthropogenic carbon and ocean pH, Nature, 425, 365-365, 2003.

Camoin, G. F. and Montaggioni, L. F.: High energy coralgalstromatolite frameworks from Holocene reefs (Tahiti, French Polynesia), Sedimentology, 41, 656-676, 1994.

Castillo, K. D., Ries, J. B., Bruno, J. F., and Westfield, I. T.: The reef-building coral Siderastrea siderea exhibits parabolic responses to ocean acidification and warming, Proc. R. Soc. B., 281, $20141856,2014$.

Comeau, S., Edmunds, P. J., Spindel, N. B., and Carpenter, R. C.: The responses of eight coral reef calcifiers to increasing partial pressure of $\mathrm{CO}_{2}$ do not exhibit a tipping point, Limnol. Oceanogr, 58, 388-398, 2013.

Cubasch, U., Wuebbles, D., Chen, D., Facchini, M. C., Frame, D., Mahowald, N., and Winther, J.-G.: Climate Change 2013: The Physical Science Basis, Contribution of Working Group I to the Fifth Assessment Report of the Intergovernmental Panel on Climate Change Cambridge, United Kingdom and New York, NY, USA, 119-158, 2013.

Davidson, T. M., de Rivera, C. E., and Carlton, J. T.: Small increases in temperature exacerbate the erosive effects of a non-native burrowing crustacean, J. Exp. Mar. Biol. Ecol., 446, 115-121, 2013.

Diaz-Pulido, G., Anthony, K., Kline, D. I., Dove, S., and HoeghGuldberg, O.: Interactions between ocean acidification and warming on the mortality and dissolution of coralline alge, J. Phycol., 48, 32-39, 2012.

Diaz-Pulido, G., Nash, M. C., Anthony, K. R. N., Bender. D., Opdyke, B. N., Reyed-Nivia, C., and Troitzsch, U.: Greenhouse conditions induce mineralogical changes and dolomite accumulation in coralline algae on tropical reefs, Nature Communications, 5, 3310, doi:10.1038/ncomms4310, 2014.

Dickson, A. G.: Standard potential of the reaction: $\mathrm{AgCl}(\mathrm{s})+$ $12 \mathrm{H}_{2}(\mathrm{~g})=\mathrm{Ag}(\mathrm{s})+\mathrm{HCl}(\mathrm{aq})$, and and the standard acidity constant of the ion $\mathrm{HSO}_{4}^{-}$in synthetic sea water from 273.15 to 318.15 K, J. Chem. Thermodyn., 22, 113-127, 1990.

Dickson, A. G. and Millero, F. J.: A comparison of the equilibrium constants for the dissociation of carbonic acid in seawater media, Deep-Sea Res.-Pt. I, 34, 1733-1743, 1987.

Dickson, A. G., Sabine, C. L., and Christian, J. R.: Guide to best practices for ocean $\mathrm{CO}_{2}$ measurements, Sidney, British Columbia, North Pacific Marine Science Organization, PICES Special Publication 3, 2007.

Doney, S. C., Fabry, V. J., Feely, R. A., and Kleypas, J. A.: Ocean Acidification: The Other $\mathrm{CO}_{2}$ Problem, Ann. Rev. Mar. Sci., 1, 169-192, 2009.

Drupp, P. S., De Carlo, E. H., Mackenzie, F. T., Sabine, C. L., Feely, R. A., and Shamberger, K. E.: Comparison of $\mathrm{CO}_{2}$ dynamics and air-sea gas exchange in differing tropical reef environments, Aquat. Geochem., 19, 371-397, 2013.

Erez, J., Reynaud, S., Silverman, J., Schneider, K., and Allemand, D.: Coral calcification under ocean acidification and global change, in: Coral Reefs: an ecosystem in transition, edited by: Dubinski, Z. and Stambler, N., Springer, 151-176, 2011.
Fabricius, K. E.: Effects of terrestrial runoff on the ecology of corals and coral reefs: review and synthesis, Mar. Pollut. Bull., 50, 125146, 2005.

Fabricius, K., Langdon, C., Uthicke, S., Humphrey, C., Noonan, S., De'ath, G., Okazaki, R., Muehllehner, N., Glas, M., and Lough, $\mathrm{J}$.: Losers and winners in coral reefs acclimatized to elevated carbon dioxide concentrations, Nature Climate Change, 1, 165-169, 2011.

Fair, R. C.: On the robust estimation of econometric models, in: Annals of Economic and Social Measurement, 3, NBER, 117128, 1974.

Fang, J. K. H., Mello-Athayde, M. A., Schönberg, C. H. L., Kline, D. I., Hoegh-Guldberg, O., and Dove, S.: Sponge biomass and bioerosion rates increase under ocean warming and acidification, Glob. Change Biol., 19, 3581-3591, 2013.

Fangue, N. A., O’Donnell, M. J., Sewell, M. A., Matson, P. G., MacPherson, A. C., and Hofmann, G. E.: A laboratory-based, experimental system for the study of ocean acidification effects on marine invertebrate larvae, Limnol. Oceanogr.-Meth., 8, 441452, 2010.

Feely, R. A., Sabine, C. L., Lee, K., Berelson, W., Kleypas, J., Fabry, V. J., and Millero, F. J.: Impact of anthropogenic $\mathrm{CO}_{2}$ on the $\mathrm{CaCO}_{3}$ system in the oceans, Science, 305, 362-366, 2004.

Findlay, H. S., Wood, H. L., Kendall, M. A., Spicer, J. I., Twitchett, R. J., and Widdicombe, S.: Comparing the impact of high $\mathrm{CO}_{2}$ on calcium carbonate structures in different marine organisms, Mar. Biol. Res., 7, 565-575, 2011.

Gattuso, J.-P., Frankignoulle, M., and Smith, S. V.: Measurement of community metabolism and significance in the coral reef $\mathrm{CO}_{2}$ source-sink debate, Proc. Natl. Acad. Sci., 96, 13017-13022, 1999.

Guadayol, Ò., Silbiger, N. J., Donahue, M. J., and Thomas, F. I. M.: Patterns in Temporal Variability of Temperature, Oxygen and $\mathrm{pH}$ along an Environmental Gradient in a Coral Reef, PloS one, 9, e85213, doi:10.1371/journal.pone.0085213, 2014.

Harrington, L., Fabricius, K., De'ath, G., and Negri, A.: Recognition and selection of settlement substrata determine postsettlement survival in corals, Ecology, 84, 3428-3437, 2004.

Hoegh-Guldberg, O., Mumby, P. J., Hooten, A. J., Steneck, R. S., Greenfield, P., Gomez, E., Harvell, C. D., Sale, P. F., Edwards, A. J., Caldeira, K., Knowlton, N., Eakin, C. M., Iglesias-Prieto, R., Muthiga, N., Bradbury, R. H., Dubi, A., and Hatziolos, M. E.: Coral reefs under rapid climate change and ocean acidification, Science, 318, 1737-1742, 2007.

Huey, R. B. and Kingsolver, J. G.: Evolution of thermal sensitivity of ecotherm performance, Trends Ecol. Evol., 4, 131-135, 1989.

Hutchings, P. A.: Biological destruction of coral reefs, Coral Reefs, 4, 239-252, 1986.

Hoegh-Guldberg, O. and Bruno, J. F.: The impact of climate change on the world's marine ecosystems, Science, 328, 1523-1528, 2010.

Hurd, C. L., Cornwall, C. E., Currie, K., Hepburn, C. D., McGraw, C. M., Hunter, K. A., and Boyd, P. W.: Metabolically induced $\mathrm{pH}$ fluctuations by some coastal calcifiers exceed projected $22 \mathrm{nd}$ century ocean acidification: a mechanism for differential susceptibility?, Glob. Change Biol., 17, 3254-3262, 2011.

Johnson, M. D. and Carpenter, R. C.: Ocean acidification and warming decrease calcification in the crustose coralline alga $\mathrm{Hy}$ - 
drolithon onkodes and increase susceptibility to grazing, J. Exp. Mar. Biol. Ecol., 434, 94-101, 2012.

Johnson, M. D., Moriarty, V. W., and Carpenter, R. C.: Acclimatization of the Crustose Coralline Alga Porolithon onkodes to Variable $p \mathrm{CO}_{2}$, PLOS ONE, 9, e87678, doi:10.1371/journal.pone.0087678, 2014.

Jokiel, P. L., Rodgers, K. S., Kuffner, I. B., Andersson, A. J., Cox, E. F., and Mackenzie, F. T.: Ocean acidification and calcifying reef organisms: a mesocosm investigation, Coral Reefs, 27, 473-483, 2008.

Jury, C. P., Thomas, F. I. M., Atkinson, M. J., and Toonen, R. J.: Buffer Capacity, Ecosystem Feedbacks, and Seawater Chemistry under Global Change, Water, 5, 1303-1325, 2013.

Kamenos, N. A., Burdett, H. L., Aloisio, E., Findlay, H. S., Martin, S., Longbone, C., Dunn, J., Widdicombe, S., and Calosi, P.: Coralline algal structure is more sensitive to rate, rather than the magnitude, of ocean acidification, Glob. Change Biol., 19, 36213628, 2013.

Kleypas, J. and Langdon, C.: Coral reefs and changing seawater chemistry, in: Coral Reefs and Climate Change: Science and Managemen., edited by: Phinney, J., Skirving, W., Kleypas, J., and Hoegh-Guldberg, O., American Geophysical Union, Washington D.C., 73-110, 2006.

Kroeker, K. J., Kordas, R. L., Crim, R. N., and Singh, G. G.: Metaanalysis reveals negative yet variable effects of ocean acidification on marine organisms, Ecol. Lett., 13, 1419-1434, 2010.

Kroeker, K. J., Kordas, R. L., Crim, R., Hendriks, I. E., Ramajo, L., Singh, G. S., Duarte, C. M., and Gattuso, J. P.: Impacts of ocean acidification on marine organisms: quantifying sensitivities and interaction with warming, Glob. Change Biol., 19, 1884-1896, 2013.

Littler, M. M.: The population and community structure of Hawaiian fringing-reef crustose corallinaceae (Rhodophyta, Cryptonemiales), J. Exp. Mar. Biol. Ecol., 11, 103-120, 1973.

Lowe, R. J., Falter, J. L., Monismith, S. G., and Atkinson, M. J.: A numerical study of circulation in a coastal reef-lagoon system, J. Geophys. Res.-Oceans, 114, C06022, doi:10.1029/2008JC005081, 2009a.

Lowe, R. J., Falter, J. L., Monismith, S. G., and Atkinson, M. J.: Wave-driven circulation of a coastal reef-lagoon system, J. Phys. Oceanogr., 39, 873-893, 2009b.

Martin, S., Cohu, S., Vignot, C., Zimmerman, G., and Gattuso, J. P.: One-year experiment on the physiological response of the Mediterranean crustose coralline alga, Lithophyllum cabiochae, to elevated $p \mathrm{CO}_{2}$ and temperature, Ecol. Evol., 3, 676-693, doi:10.1029/2008JC005081, 2013.

Mehrbach, C.: Measurement of the apparent dissociation constants of carbonic acid in seawater at atmospheric pressure, Limnol. Oceanogr., 18, 897-907, 1973.

Meinshausen, M., Smith, S. J., Calvin, K., Daniel, J. S., Kainuma, M. L. T., Lamarque, J. F., Matsumoto, K., Montzka, S. A., Raper, S. C. B., and Riahi, K.: The RCP greenhouse gas concentrations and their extensions from 1765 to 2300, Clim. Change, 109, 213$241,2011$.

Pandolfi, J. M., Connolly, S. R., Marshall, D. J., and Cohen, A. L.: Projecting coral reef futures under global warming and ocean acidification, Science, 333, 418-422, 2011.
Price, N.: Habitat selection, facilitation, and biotic settlement cues affect distribution and performance of coral recruits in French Polynesia, Oecologia, 163, 747-758, 2010.

Pörtner, H. O., Bennet, A. F., Bozinovic, F., Clarke, A., Lardies, M. A., Lucassen, M., Pelster, B., Schiemer, F., and Stillman, J. H.: Trade-offs in therman adaptation: the need for molecular ecological integration, Phys. Biochem. Zool., 79, 295-313, 2006.

Putnam, H. M.: Resilience and acclimatization potential of reef corals under predicted climate change stressors, $\mathrm{PhD}$, Zoology, University of Hawaii at Manoa, Honolulu, 1-154, 2012.

Reyes-Nivia, C., Diaz-Pulido, G., Kline, D., Guldberg, O.-H., and Dove, S.: Ocean acidification and warming scenarios increase microbioerosion of coral skeletons, Glob. Change Biol., 19, 1919-1929, 2013.

Ries, J. B., Cohen, A. L., and McCorkle, D. C.: Marine calcifiers exhibit mixed responses to $\mathrm{CO}_{2}$-induced ocean acidification, $\mathrm{Ge}$ ology, 37, 1131-1134, 2009.

Rodolfo-Metalpa, R., Houlbrèque, F., Tambutté, É., Boisson, F., Baggini, C., Patti, F. P., Jeffree, R., Fine, M., Foggo, A., and Gattuso, J. P.: Coral and mollusc resistance to ocean acidification adversely affected by warming, Nature Climate Change, 1, 308-312, 2011.

Rogelj, J., Meinshausen, M., and Knutti, R.: Global warming under old and new scenarios using IPCC climate sensitivity range estimates, Nature Climate Change, 2, 248-253, 2012.

Sanford, T., Frumhoff, P. C., Luers, A., and Gulledge, J.: The climate policy narrative for a dangerously warming world, Nature Climate Change, 4, 164-166, 2014.

Semesi, I. S., Kangwe, J., and Björk, M.: Alterations in seawater pH and $\mathrm{CO}_{2}$ affect calcification and photosynthesis in the tropical coralline alga, Hydrolithon sp. (Rhodophyta), Estuarine, Coast. Shelf Sci., 84, 337-341, 2009.

Silbiger, N., Guadayol, Ò., Thomas, F. I. M., and Donahue, M.: Reefs shift from net accretion to net erosion along a natural environmental gradient, Mar. Ecol. Prog. Ser., 515, 33-44, 2014.

Smith, S. V. and Key, G. S.: Carbon dioxide and metabolism in marine environments, Limnol. Oceanogr, 20, 493-495, 1975.

Smith, S. V., Kimmerer, W. J., Laws, E. A., Brock, R. E., and Walsh, T. W.: Kaneohe Bay sewage diversion experiment - perspectives on ecosystem responses to nutritional perturbation, Pacific Science, 35, 279-402, 1981.

Solomon, S., Qin. D., Manning. M. Chen. Z., Marquis, M., Bindoff, N. L., Willebrand, J., Artale, V., Cazenave, A., Gregory, J., Gulev, S., Hanawa, K., Le Quéré, C., Levitus, S., Nojiri, Y., Shum, C. K., Talley L. D., and Unnikrishnan, A.: Observations: Oceanic Climate Change and Sea Level, in: Climate Change 2007: The Physical Science Basis, Contribution of Working Group I to the Fourth Assessment Report of the Intergovernmental Panel on Climate Change, edited by: Solomon, S., Qin, D., Manning, M., Chen, Z., Marquis, M., Averyt, K. B., Tignor, M., and Miller, H. L., Cambridge University Press, Cambridge, United Kingdom and New York, NY, USA, 387-429, 2007.

Stimson, J. and Kinzie III, R. A.: The temporal pattern and rate of release of zooxanthellae from the reef coral Pocillopora damicornis (Linnaeus) under nitrogen-enrichment and control conditions, J. Exp. Mar. Biol. Ecol., 153, 63-74, 1991.

Tans, P. and Keeling, R.: NOAA/ESRL, available at: www.esrl. noaa.gov/gmd/ccgg/trends/ (last access: 8 January 2015), 2013. 
Tribollet, A. and Payri, C.: Bioerosion of the coralline alga $\mathrm{Hy}$ drolithon onkodes by microborers in the coral reefs of Moorea, French Polynesia, Oceanol. Acta, 24, 329-342, 2001.

Tribollet, A., Atkinson, M. J., and Langdon, C.: Effects of elevated $p \mathrm{CO}_{(2)}$ on epilithic and endolithic metabolism of reef carbonates, Glob. Change Biol., 12, 2200-2208, 2006.

Tribollet, A., Godinot, C., Atkinson, M., and Langdon, C.: Effects of elevated $\mathrm{pCO}_{(2)}$ on dissolution of coral carbonates by microbial euendoliths, Glob. Biogeochem. Cy., 23, GB3008, doi:10.1029/2008GB003286, 2009.

Uppström, L. R.: The boron/chlorinity ratio of deep-sea water from the Pacific Ocean, Deep-Sea Res., 21, 161-162, 1974.

Van Heuven, S., Pierrot, D., Lewis, E., and Wallace, D. W. R.: MATLAB Program developed for $\mathrm{CO}_{2}$ system calculations, Rep. ORNL/CDIAC-105b, 2009.

van Heuven, S., Pierrot, D., Rae, J. W. B., Lewis, E., and Wallace, D. W. R.: 5 MATLAB program developed for $\mathrm{CO}_{2}$ system calculations, ORNL/CDIAC-105b, Carbon Dioxide Inf. Anal. Cent., Oak Ridge Natl. Lab., US DOE, Oak Ridge, Tenn., doi:10.3334/CDIAC/otg.CO2SYS_MATLAB_v1.1, 2011.

Van Vuuren, D. P., Meinshausen, M., Plattner, G. K., Joos, F., Strassmann, K. M., Smith, S. J., Wigley, T. M. L., Raper, S. C. B., Riahi, K., and De La Chesnaye, F.: Temperature increase of 21st century mitigation scenarios, Proc. Natl. Acad. Sci., 105, 15258-15262, 2008.
Van Vuuren, D. P., Edmonds, J., Kainuma, M., Riahi, K., Thomson, A., Hibbard, K., Hurtt, G. C., Kram, T., Krey, V., and Lamarque, J.-F.: The representative concentration pathways: an overview, Clim. Change, 109, 5-31, 2011.

White, J.: Distribution, recruitment and development of the borer community in dead coral on shallow Hawaiian reefs, Ph.D., Zoology, University of Hawaii at Manoa, Honolulu, 1980.

Wisshak, M., Schönberg, C. H. L., Form, A., and Freiwald, A.: Ocean acidification accelerates reef bioerosion, Plos One, 7, e45124, doi:10.1371/journal.pone.0045124, 2012.

Wisshak, M., Schönberg, C. H. L., Form, A., and Freiwald, A.: Effects of ocean acidification and global warming on reef bioerosion - lessons from a clionaid sponge, Aquat. Biol., 19, 111-127, 2013.

Wolf-Gladrow, D. A., Zeebe, R. E., Klass, C., Körtzinger, A., and Dickson, A. G.: Total Alkalinity: The explicit conservative expression and its application to biogeochemical processes, Mar. Chem., 106, 287-300, 2007.

Yates, K. K. and Halley, R. B.: $\mathrm{CO}_{3}^{2-}$ concentration and $p \mathrm{CO}_{2}$ thresholds for calcification and dissolution on the Molokai reef flat, Hawaii, Biogeosciences, 3, 357-369, doi:10.5194/bg-3-3572006, 2006. 